\title{
The role of procurement procedures in environmental management: A case study of classified hotels in Mombasa County, Kenya
}

\author{
Jane Akinyi Odeny ${ }^{1 *}$, Shem Maingi ${ }^{2}$, Joseph Kurauka ${ }^{3}$ \\ ${ }^{1}$ Machakos University, Department of Hospitality Management, Machakos, Kenya \\ ${ }^{2}$ Kenyatta University, Department of Hospitality and Tourism Management, Nairobi, \\ Kenya \\ ${ }^{3}$ Kenyatta University, Department of Environmental Studies and Community Development, \\ Nairobi, Kenya
}

\begin{abstract}
This paper sought to examine the role of procurement procedures on environmental management. It adopted a cross-sectional descriptive research design that involved collecting and analyzing data of observations about the role of procurement practices on environmental management froma representative sample of managerial staff of classified hotels in Mombasa County, Kenya. The data collected was primary data. It was collected fromstaff in 69 hotels in Mombas a County, Kenya. The research used stratified random sampling technique where the employees were categorised into seven strata of general/assistant managers, food and beverage managers, executive chef, procurement officers, maintenance managers, receiving managers and housekeepers. From each of the stratum, a random sample was identified. The study employed Yamane's formula to determine the sample size. The study determined that procurement procedures influenced environmental management. The study also determined that some of the procurement procedures were perceived to have a greater influence than others. The most influential procurement procedure on environmental management is tendering adverts that attract suppliers offering environmentally friendly products, while the least influential is assessing the impact of suppliers on the environment prior to purchasing.
\end{abstract}

Keywords: procurement procedures, environmental management, clas sified hotels JEL classification: Z32, Q56

\section{Uloga postupaka nabavke u upravljanju životnom sredinom: Studija slučaja kategorisanih hotela u okrugu Mombasa, Kenija}

Sažetak: Rad ima za cilj da ispita ulogu procedura nabavke u upravljanju životnom sredinom. Korišćen je deskriptivni is traživački pristup koji je uključio prikupljanje i an alizu podataka o zapažanjima reprezentativnog uzorka rukovodećeg osoblja kategorisanih hotela u okrugu Mombasa u Keniji o ulozi nabavke u upravljanju životnom sredinom. Prikupljeni podaci su primarnog karaktera. Podaci su prikupljeni ispitivanjem osoblja u 69 hotela u okrugu Mombasa u Keniji. U istraživanju se koristila stratifikovana tehnika slučajnog uzorkovanja gde su zaposleni kategorisani u sedamnivoa generalnih menadžera i pomoćnika

*akinyiotieno45@yahoo.com 
direktora, menadžera hrane ipića, šefa kuhinje, s lužbenika nabavke, menadžera održavanja, menadžera za prijem i upravitelja domaćinstva. Iz svakog nivoa je identifikovan nasumični uzorak. U studiji se koristila Yamane-ova formula za određivanje veličine uzorka. Istraživanje je potvrdilo da procedure nabavke utiču na uprav ljanje životnom sredinom. Is traživanje je, takođe, potvrdilo da neki od postupaka nabavke imaju veći uticaj od drugih. Postupak nabavke sa najvećimuticajemna upravljanje životnom sredininom je ras pisivanje tendera koji privlače dobavljače koji nude ekološke proizvode, dok procena uticaja dobavljača na okruženje pre kupovine ima najmanji uticaj.

Ključne reči: procedure nabavke, upravljanje životnom sredinom, kategoris ani hoteli JEL klasifikacija: Z32, Q56

\section{Introduction}

The Hospitality and Tourismindustry is very important to the Kenyan economy. Kenya earned 96 billion shillings from foreign exchange, contributed 8.3 per cent in employment countrywide in 2012 (KNBS, 2016, p. 38). Kenya Touris m Federation (2014), explains that hospitality sector is one of the biggest producers of waste food. However, the report observed that $40-60 \%$ of the hotels located on the Coastal region do not have green management supply design. This has led to hips of garbage and litter in the environment, which has resulted to high carbon emis sions that are harmful to both fauna and flora. Kenya Touris mFederation (2014) specifies that, Kenya in particular, generates tons of was te each year. The Sustainable TourismReport (2013), cautions that, "the survival of the Hos pitality and Tourism industry depends on environmental conservation" (p. 55).

Procurement Procedures are a necessary component of Supply Chain Management (SCM). "It reflects the need to include suppliers as part of the implementation of environmentally sound practices for materials management and purchasing proces ses and procedures, tantamount to greening the supplier" (Srivas tava, 2005, p. 75). Procurement procedures are measured the techniques used in acquiring raw materials, suppliers who are able to source environmentally friendly materials and materials such as organic and natural products applied by the hotels. Knudsen (2013) notes that "supply chain management practices are the integration of improvement of the environment and curbing of natural risks" (p. 18). Wu et al. (2012) explains that supply chain management practices are actions, procedures, processes and activities that are friendly to the environment. Environmental responsibility has lately become a corporate issue as it has drawn special attention es pecially in the hotel industry (Khisa, 2011).

There are three levels of SCM practices proposed to result from different combin ations of drivers and supply chain management practices. When a firm is motivated mainly by internal and externaldrivers and possesses low supply chain capabilities, we expect internal (mainly manufacturing), reactive or 'end-of-pipe' green practices, where a firm tries only to 'clean' negative environmental impacts with minimum implementation of proactive practices. The study aimed at investigating the role of supply chain management practices in environmental management in clas sified hotels in MombasaCounty, Kenya. Thus, this study was based on the following hypothes is: there is no significant relationship between the procurement procedures and environmental management in clas sified hotels in Mombasa County, Kenya.

\section{Literature review}

“A firm's procurement systemis a vital component of a company's supply chain system" (Janković \& Krivačić, 2014, p. 15). “Typically, a company’s procurement function is 

hotels in Mombasa County, Kenya - Hotel and Tourism Management, 2020, Vol. 8, No. 1: 11-23.

subdivided into strategic and operational processes since activities and priorities in these two areas are entirely different"(Amemba, 2013, p. 36). Due to the importance of procurement in an organization, some organizations haveenhanced their procurement processes by adoptin $\mathrm{g}$ new systems such as e-procurement that is used in conjunction with the changed technologies of electronic trade such as archive imaging, work process management, announcement boards and email to empower bu sinessprocess reengineering. Organizations acquisition enables purchasers to buy goods and services using various facilities in an as sortment of forms. Most importantly, parastatals see acquirement as a decent chance to upgrade and enhance productivity in obtainment procedures among people in general se ctor bodies. These procedures are exceptionally directed, with specific rules for advertising obtainment needs.

As accurately featured by Siem(2005), government procurement procedures could be guided by three fundamental principles: every single interested gathering in all part states must have an equivalent chance to submit tenders, all enquiries must get equivalent treatment keeping in mind the end goal to wipe out discrimination on the grounds of the nationality of the contractual worker or the starting point of the goods/services and each of the offering and honor procedures must include the utilization of target criteria. "W ith these combinations, eprocurement can give rise to a number of benefits to an organization and to the strategic position of a firm such that it will consolidate purchasing practices that will prompt more prominent discounts and better service from suppliers, quicken the stream of critical data between the purchaser and supplier, decrease administrative hours, liberating them up to do other work and furthermore helps to res pond rapidly to very aggressivenew market entrants" (Chiu \& Hsieh, 2015, p. 114).

$\mathrm{Wu}$ et al. (2012) as sert that policy makers are increasingly showing interest in unethical processes that transpire in the procurement front since little progress has been achieved. To a competent supply organization, the award of tender should ensure effective delivery of goods of cost, time and quality standard. It is generally accepted that the main goals in any supply are budget, schedule and quality (Perry \& Sohal, 2009). Meeting goals related to cost, schedule, quality and safety is the overall success of a supply. To ensure performance of the supply in relation to the above-mentioned variables is therefore the objective of taking all the required precautions and due processes in the selection of supplier to execute a market tender.

Hos ke (2015) proposes prequalifying of suppliers before the process of bidding to as certain their ability to meet project and client objectives as a method of improving performance on construction. Thus, capable, competent and competitive suppliers' prequalification is key to determining the awarding of tenders. The tendency of suppliers to be sophisticated is a fact and it is therefore necessary to explore the effect of service delivery by supplier's prequalification. When procedures and procurement standards are stipulated, the competencies types of procurement operations staff are affected indirectly by the legal framework. However, some cas es are different, as in the US procurement legal frameworks according to Illinois Public Higher Education Procurement where quality and type of staff competencies by implication are suggested openly (Manyara \& Jones, 2007).

According to Mensah (2016), the Kenyan procurement management heavily suffers from unethical practices and it is thus necessary to make ethical considerations in order to reestablish public trust. Green et al. (2012) asserts that the most common challenge undermining the battle against corruption is the maintenance of secretive relationships in procurement. Corruption and conflict of interest, among other deceptive practices in procurement pose is sues that are damaging to the purchasing department itself, relations with other departments, and suppliers. 


\section{Materials and methods}

This study adopted a cros s-sectional descriptiveres earch design that involved collecting and analyzing data of observations about the role of procurement practices in environmental management from a representative sample of managerial staff of classified hotels in Mombas aCounty, Kenya. Kothari (2004) ass erts that "cross-sectional descriptive surveys are useful in establishing practices, attitudes, knowledge and beliefs of either an entire population or a subset" (p. 18). Data was collected from individuals selected.

The collected data was primary ones, collected fromstaff in 69 hotels in Mombasa County, Kenya. These hotels were identified us ing a list developed by the Tourism Regulatory Authority in Kenya.

The unit of analysis was the managerial staff, supervisors and housekeepers. The management was targeted as they are well informed of the procurement practices at the policy implementation level while the housekeepers ensure the daily operations of the hotel in relation to environmental management in their hotels. Table 1 shows the strata distribution in the hotels.

Table 1: Target population dis tribution

\begin{tabular}{|c|c|c|c|c|c|c|}
\hline \multirow{2}{*}{ Section Managers } & \multicolumn{5}{|c|}{ Classified hotels } & \multirow{2}{*}{ Population } \\
\hline & $*$ & $* *$ & $* * *$ & $* * * *$ & $* * * * *$ & \\
\hline General or As sistant Managers & 15 & 20 & 17 & 15 & 2 & 69 \\
\hline Food and Beverage Managers & 0 & 0 & 17 & 15 & 2 & 34 \\
\hline Executive Chef & 0 & 0 & 17 & 15 & 2 & 34 \\
\hline Procurement Managers & 0 & 0 & 17 & 15 & 2 & 34 \\
\hline Maintenance Managers & 0 & 0 & 0 & 15 & 2 & 17 \\
\hline Receiving Managers & 0 & 0 & 0 & 15 & 2 & 17 \\
\hline Hous ekeepers & 0 & 0 & 2 & 15 & 2 & 19 \\
\hline Total $(\mathbf{N})$ & 15 & 20 & 70 & 105 & 14 & 224 \\
\hline
\end{tabular}

Key (Hotel rating): * One-star, ** Two-star, *** Three-star, **** Four-star, ***** Five-star Source: Author's research, 2017

The research used stratified randoms ampling. This technique fits the study as it gives each element within each stratum an equal probability of being selected (Den scombe, 2008). From each stratum(Table 1), a random sample was identified. Collecting data from each stratum ensured representativeness of the sample, while random selection within the strata reduced bias ness in selecting the respondents. The study adopted Yamane's formulae (equation 1) to determine an adequate sample size, $n$, of the survey (Yamane, 1967):

Where:

$$
n=\frac{N}{1+N(e)^{2}}
$$

$n$ is the optimum sample size,

$N$ - the number of managerial staff in the classified hotels in Mombas a County (224), $e$ - the probability of error (i.e. the desired precision, i.e. 0.05 for $95 \%$ confidence level).

Sample size, $n$ :

$$
172=\frac{224}{1+224(0.05)^{2}}
$$

To minimize bias so as to ensure the reliability and validity of the findings, a proportionate sample for each segment of the stratum was identified as shown in Table 2. 
Table 2: Sampling frame

\begin{tabular}{|l|c|c|c|}
\hline Sections & Population & Sample size & Percentage \\
\hline General/ Assistant managers & 69 & 53 & 31 \\
\hline Food and beverage managers & 34 & 26 & 15 \\
\hline Executive Chef & 34 & 26 & 15 \\
\hline Procurement managers & 34 & 26 & 15 \\
\hline Maintenance managers & 17 & 13 & 8 \\
\hline Receiving managers & 17 & 13 & 8 \\
\hline Housekeepers & 19 & 15 & 8 \\
\hline Total & $\mathbf{2 2 4}$ & $\mathbf{1 7 2}$ & $\mathbf{1 0 0}$ \\
\hline
\end{tabular}

Source: Author's research, 2017

A non-structured questionnaire is a questionnaire where the listing of questions is in a prearranged order and where the purpose of the data is revealed to the respondents. The choice of three ins truments was to en sure triangulation was achieved. Most of the questions were close-ended to allow eas y coding, faster res ponses and direct research to relevant and desirable variables hypothesized as pos sible challenges. The 5-point Likert type scale was adopted for the study. "The Likert scale used was $1=$ strongly disagree, $2=$ disagree, $3=$ indifferent (neutral), 4= agree and 5=strongly agree" (Denscombe, 2008, p. 34). The rationale for choosing thequestionnaire as the research instrument was primarily due to its practicability, applicability to the res earch problemand the size of the population. It is also cost effective (Denscombe, 2008). The questionnaire was organised into two parts; the first part sought information on the res pondent's demography, which included their job category, length of time in the hotel, the operational time of the hotel as well as its rating. The second section, i.e. part B, contained the questions related to supply procurement practices.

A pretest was done to eliminate possible flaws in data collection procedures. Some questionnaires were dis tributed to managerial and support staff in hotels of similar caliber in NairobiCounty. Eleven questionnaires were collected for scrutiny before the data in them was analyzed (Table 3). Mugenda and Mugenda (2003) state that a "relatively small sample of 10 to 20 respondents can be chosen from the population during piloting which is not included in the sample chosen for the main study" (p. 55).

Table 3: Hotels sampled and response rate

\begin{tabular}{|l|c|c|}
\hline Classification (Hotel rating) & $\begin{array}{c}\text { Ques tionnaires issued } \\
\text { per hotel }\end{array}$ & Questionnaires received \\
\hline$*$ & 4 & 3 \\
\hline$* *$ & 4 & 2 \\
\hline$* * *$ & 4 & 2 \\
\hline$* * * *$ & 4 & 2 \\
\hline$* * * * *$ & 4 & 2 \\
\hline Total & $\mathbf{2 0}$ & $\mathbf{1 1}$ \\
\hline
\end{tabular}

Source: Author's research, 2017

Reliability was estimated using Cronbach's Alpha Coefficient. A reliability of at least 0.70 at $\alpha=0.05$ significance level of confidence is acceptable (Coopper \& Schidlers, 2003). Table 4 shows the reliability analysis table. The universally acceptable Likert scale items were used in gathering data to enhance criterion validity. The help of an expert was sought in their preparation to ensure content validity. 
Table 4: Reliability analysis

\begin{tabular}{|l|c|c|}
\hline Dimension & $\begin{array}{c}\text { Cronbach's Alpha } \\
\text { Reliability Coefficients }\end{array}$ & $\begin{array}{c}\text { Evaluation based on } \\
\text { Sekaran } \\
\text { (2000) }\end{array}$ \\
\hline Procurement procedures & 0.962 & Acceptable \\
\hline
\end{tabular}

Source: Author's research, 2017

In total 172 questionnaires were administered through direct interaction with the respondents. However, in a case where the collection of data through face to face proved difficult, the researcher used the drop and pick method.

Statistical Package for Social Sciences (SPSS) was used to analyze the data. Most of the data was analyzed by use of descriptive statistics. Chi-square was employed to establish a relationship between variables. A repeated meas ure ANOVA was conducted to examine the influence of seven procurement procedures on environmental management in classified hotels using Likert scale values where $1=$ not at all influential, $2=$ slightly influential, $3=$ somewhat influential, $4=$ very influential and $5=$ extremely influential. Table 5 shows Measurement of Constructs.

Table 5: Measurement of constructs

\begin{tabular}{|l|l|}
\hline \multicolumn{1}{|c|}{ Objective } & \multicolumn{1}{|c|}{ Scaling } \\
\hline $\begin{array}{l}\text { To examine the influence of procurement procedures on } \\
\text { environmental management in classified hotels within } \\
\text { Mombasa County, Kenya. }\end{array}$ & $\bullet$ Ordinal \\
\hline
\end{tabular}

Source: Author's research, 2017

The hypothesis was tested using Chi-square analysis. This analysis was used in order to establish the existence of an as sociation between variables: $\mathrm{Phi}=0.000$ an association exis ts.

\section{Results and discussion}

This section presents the findings and discussions on the roles of procurement procedures in environmental management of classified hotels in Mombasa County in Kenya.

Table 6 shows data on the number of hotels sampled and the response rate. According to Chege (2012, p. 25) and Chan et al. (2015, p. 51), "a survey with an overall response rate of more than 59 percent shows the success of the survey". The response rate was $61 \%$.

Table 6: Hotels sampled and response rate

\begin{tabular}{|l|c|c|c|c|}
\hline $\begin{array}{l}\text { Classified } \\
\text { hotels }\end{array}$ & Number & $\begin{array}{c}\text { Questionnaires } \\
\text { issued per hotel }\end{array}$ & $\begin{array}{c}\text { Total } \\
\text { questionnaires } \\
\text { issued }\end{array}$ & $\begin{array}{c}\text { Questionnaires } \\
\text { received }\end{array}$ \\
\hline$*$ & 15 & 2 & 30 & 27 \\
\hline$* *$ & 20 & 2 & 40 & 30 \\
\hline$* * *$ & 17 & 3 & 51 & 24 \\
\hline$* * * *$ & 15 & 3 & 45 & 18 \\
\hline$* * * * *$ & 2 & 3 & 6 & 6 \\
\hline Total & $\mathbf{6 9}$ & & $\mathbf{1 7 2}$ & $\mathbf{1 0 5}$ \\
\hline
\end{tabular}

Source: Author's research, 2017

Data on the management positions held by the participants indicated that they worked in 
eight management positions in the clas sified hotels. The findings showed that the number of respondents in the various positions varied as presented in Table 7.

Table 7: Data on the management pos itions held by the participants

\begin{tabular}{|l|c|c|}
\hline Management position & Frequency & Percent \\
\hline General/assistant general manager & 21 & 20.0 \\
\hline Food and beverage manager & 15 & 14.2 \\
\hline Executive chef & 13 & 12.3 \\
\hline Procurement/supplies manager & 15 & 14.2 \\
\hline Maintenance manager & 11 & 10.4 \\
\hline House-keeping manager & 12 & 11.6 \\
\hline Front office manager & 8 & 7.8 \\
\hline Marketing manager & 10 & 9.5 \\
\hline Total & $\mathbf{1 0 5}$ & $\mathbf{1 0 0 . 0}$ \\
\hline
\end{tabular}

Source: Author's research, 2017

This is in line with Carter's (2014) view that support from middle level managers in organizations is key to successful implementations of GSCM practices.

Figure 1 shows the length of time served by the participants in the classified hotels. According to Murutu (2016) the working experience of the workforce positively correlates with successful supply chain performance given the fact that the members of an organization have significant information on a firm's overall procurement strategy. Cons equently, they could be as sumed to understand well the hotels procurement practices and the environment.

Figure 1: Length of time served by the participants in the classified hotels

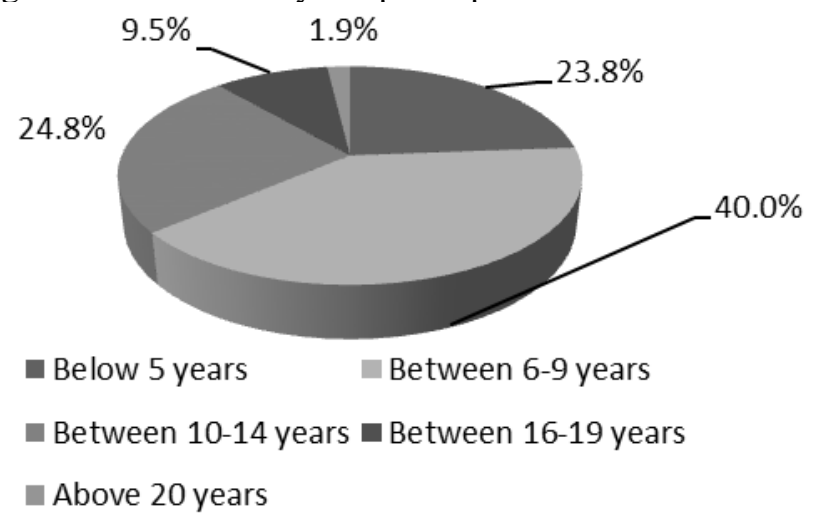

Source: Author's research, 2017

Figure 2 shows that most of the classified hotels (39\%) had been in operation for a period of between 16 to 19 years, while $2 \%$ had been in operation for a period of above 20 years. This shows that the classified hotels had been long in existence and this made the hotels conducive for the study. 
Figure 2: Length of time the classified hotels have been in operation

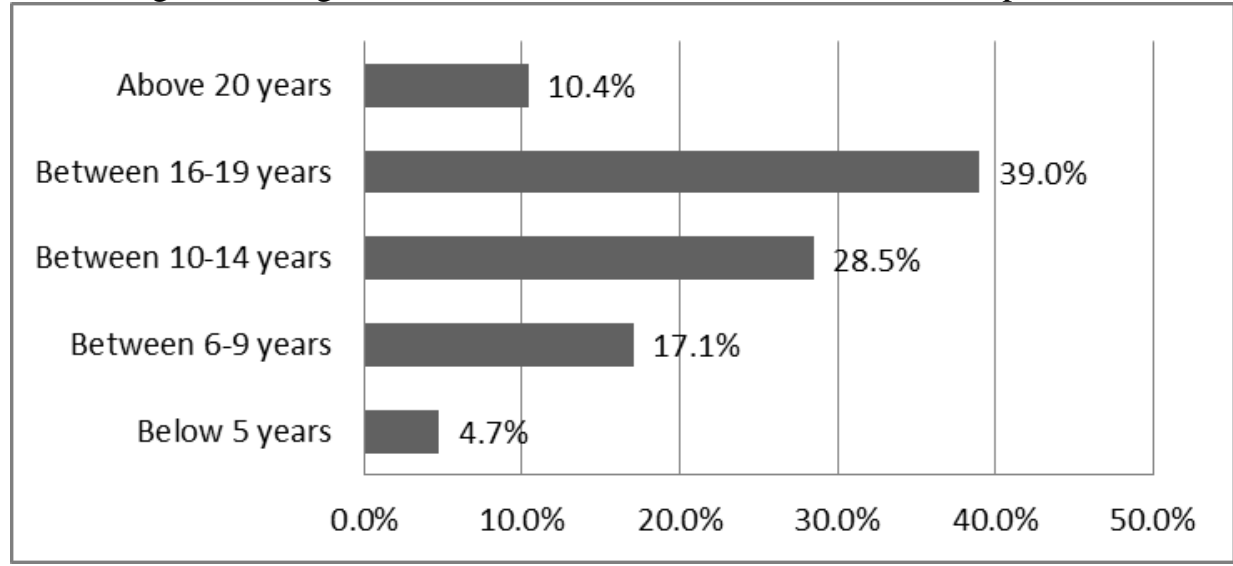

Source: Author's research, 2017

Figure 3 shows the star rating of the hotels under study. A majority of the hotels are 2-star hotels.

Figure 3: The Star ratings of the clas sified hotels

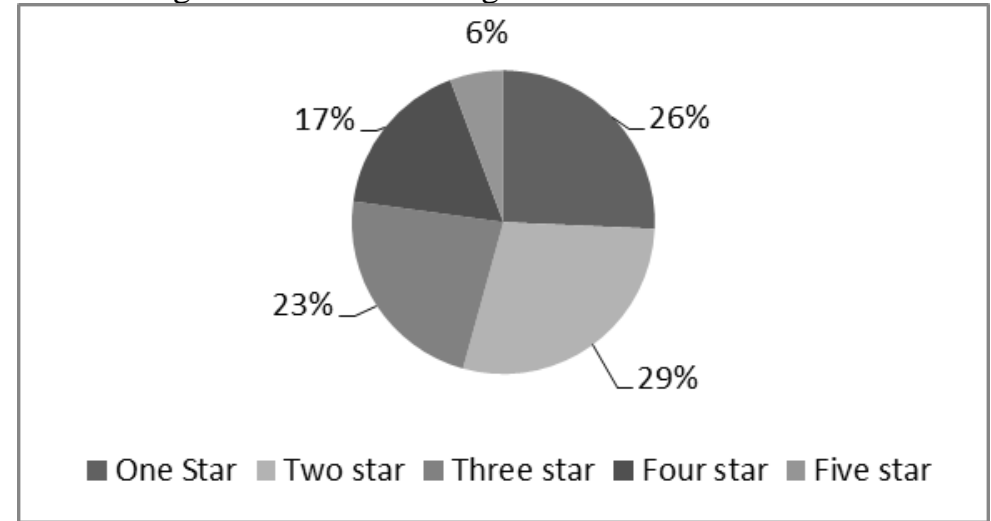

Source: Author's research, 2017

Figure 4 shows the ISO 9001 certification status of the clas sified hotels. ISO certification requires adherence to laid down environmental protection procedures.

Figure 4: ISO 9001 certification status of the classified hotels

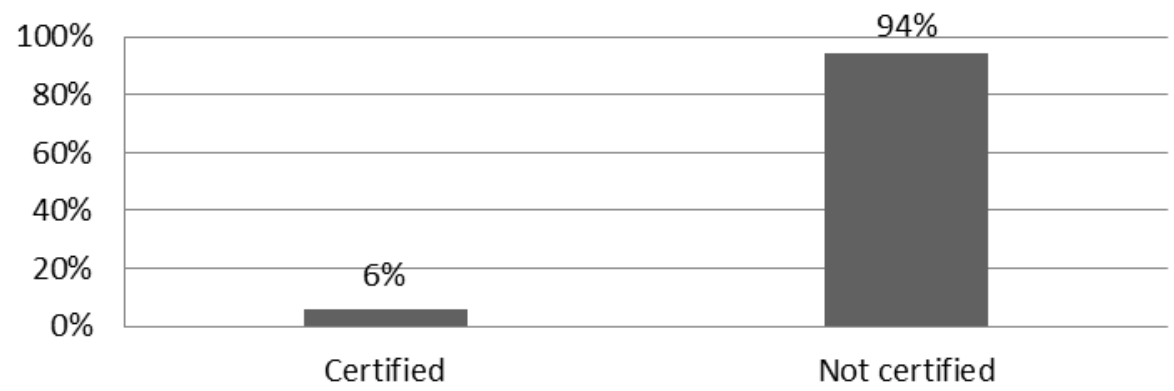

Source: Author's research, 2017 

hotels in Mombasa County, Kenya - Hotel and Tourism Management, 2020, Vol. 8, No. 1: 11-23.

Table 8 shows the descriptive statistics of the influence of procurement procedures on the environmental management.

Table 8: Descriptive statistics of the influence of procurement procedures on environmental management

\begin{tabular}{|c|c|c|c|c|c|c|c|c|c|c|c|c|}
\hline \multirow[b]{2}{*}{ Procurement procedures } & \multicolumn{2}{|c|}{\begin{tabular}{|l|} 
Strongly \\
disagree
\end{tabular}} & \multicolumn{2}{|c|}{ Dis agree } & \multicolumn{2}{|c|}{ Neutral } & \multicolumn{2}{|c|}{ Agree } & \multicolumn{2}{|c|}{$\begin{array}{c}\text { Strongly } \\
\text { agree }\end{array}$} & \multirow[b]{2}{*}{ Mean } & \multirow[b]{2}{*}{$\begin{array}{c}\text { Std. } \\
\text { Deviation }\end{array}$} \\
\hline & $\mathbf{F}$ & $\%$ & $\mathbf{F}$ & $\%$ & $\mathbf{F}$ & $\%$ & $\mathbf{F}$ & $\%$ & $\mathbf{F}$ & $\%$ & & \\
\hline $\begin{array}{l}\text { Tendering adverts that } \\
\text { attract suppliers offering } \\
\text { environmentally } \\
\text { friendly products }\end{array}$ & 1 & 1 & 3 & 3 & 11 & 10 & 53 & 50 & 37 & 35 & 3.19 & 0.785 \\
\hline $\begin{array}{l}\text { Assessing of suppliers } \\
\text { on environmentally } \\
\text { friendly practices }\end{array}$ & - & - & - & - & 6 & 6 & 81 & 77 & 17 & 16 & 2.79 & 0.583 \\
\hline $\begin{array}{l}\text { Having suppliers } \\
\text { comply with acceptable } \\
\text { environmental } \\
\text { certification standards }\end{array}$ & 1 & 1 & 2 & 2 & 9 & 9 & 63 & 60 & 21 & 20 & 2.98 & 0.693 \\
\hline $\begin{array}{l}\text { All bidders meet } \\
\text { environmental } \\
\text { certification standards }\end{array}$ & - & - & - & - & - & - & 89 & 85 & 16 & 15 & 3.12 & 0.804 \\
\hline $\begin{array}{l}\text { Assessing the impact of } \\
\text { suppliers on the } \\
\text { environment prior to } \\
\text { purchasing }\end{array}$ & - & - & - & - & 9 & 9 & 72 & 69 & 24 & 23 & 2.84 & 0.600 \\
\hline $\begin{array}{l}\text { Only purchasing from } \\
\text { suppliers selling } \\
\text { environmentally } \\
\text { friendly products }\end{array}$ & 1 & 1 & 1 & 1 & 19 & 18 & 61 & 58 & 23 & 22 & 2.86 & 0.501 \\
\hline Total & & & & & & & & & & & 20.9 & 4.783 \\
\hline Average & & & & & & & & & & & 2.99 & 0.683 \\
\hline
\end{tabular}

Source: Author's research, 2017

The descriptive statistics indicated that overall, respondent perceived all the procurement procedures to influence environmental management in the clas sified hotels. The survey conducted revealed that majority of the respondents $(85 \%)$ agreed that all bidders that met environmental certification standards influenced environmental management; 77\% agreed that assessing suppliers on environmentally friendly practices influenced environmental management; $69 \%$ agreed that assessing the impact of suppliers on the environment prior to purchasing influenced environmental management. Furthermore, $60 \%$ agreed that having suppliers comply with acceptable environmental certification standards influenced environmental management; 58\% agreed that only purchasing from suppliers selling environmentally friendly products influenced environmental management; $57 \%$ agreed that having bidders that met environmental certification standards influenced environmental management and 50\% agreed that tendering adverts that attracted suppliers offering environmentally friendly products influenced environmental management.

Housekeepers where as ked to explain the importance of sustainable development for the hotelindustry in general. According to the responses, given sustainable development has 
Odeny, J. A. et al. - The role of procurement procedures in environmental management: A case study of classified hotels in Mombasa County, Kenya - Hotel and Tourism Management, 2020, Vol. 8, No. 1: 11-23.

enhanced purchasing of only environmentally friendly products by the hotels, has enhanced environmentally friendly production processes and has reduced harmful emissions and pollution control in the hotels. One of the interviewees said: "Sustainable development for the hotel industry is the best thing for this country in the realization of vision 2030 and boosting oflocal tourism and the economy".

The findings agree with various arguments. "Environmental management issues have been important to the hotels" (Knudsen, 2013, p. 36). The availability, characteristics, knowledge, ambitions, equipment and actions of the suppliers can have an impact on purchasing and green purchasing especially by hotels (Knudsen, 2013). The result concurs with Trochim (2001) argument that the main sustainable procurement strategies include supplier capacity development, sustainability criteria in contract, vendor as ses sment and sustainable supply roles. Sarkis's (2001) argument that sustainable procurement strategies should be supported by clear lines of accountability, with incentives and penalties for delivery, are intended for the clas sified hotels having bidders that meet environmental certification standards, having suppliers comply with acceptable environmental certification standards, having all bidders meet environmental certification standards, as sessing the impact of suppliers on the environment prior to purchasing and on environmentally friendly practices. The findings about the influence of only purchasing from suppliers selling environmentally friendly products agree with Butler's (2015) view that "companies need to monitor the environmental impact of suppliers, and develop an environmental purchasing policy that aims to reduce the environmental impact of their own and their suppliers activities, goods and services (otherwise known as 'green buying')" (p. 25).

The respondents ranked the procurement policies and regulations as they were applied in their hotels. Table 9 shows that majority of the res pondents $(42 \%)$ ranked training of staff on the procurement policies as the highest procurement policy. Involvement of suppliers in ensuring compliance with procurement policies was ranked lowest at $6 \%$.

Table 9: Application of procurement policies in the clas sified hotels

\begin{tabular}{|l|c|c|}
\hline Procurement procedures & Frequency & Percentage \\
\hline $\begin{array}{l}\text { Favouring local products that comply with existing } \\
\text { regulations where possible }\end{array}$ & 29 & 28 \\
\hline $\begin{array}{l}\text { Purchasing appliances and other equipment that are } \\
\text { designed for minimum water and energy consumption }\end{array}$ & 17 & 16 \\
\hline $\begin{array}{l}\text { Training staff on the procurement policies set by the hotel } \\
\text { industry }\end{array}$ & 42 & 40 \\
\hline $\begin{array}{l}\text { Involving suppliers in ensuring compliance with } \\
\text { procurement policies by the hotel }\end{array}$ & 6 & 6 \\
\hline Preference of products with recyclable packaging & $\mathbf{1 0 5}$ & $\mathbf{1 0 0}$ \\
\hline Total
\end{tabular}

Source: Author's research, 2017

These results als o support Chiu and Hsieh's (2015) opinion that "procuring organizations are more seriously involved in designing and implementing sustainable procurement policies focusing on how environmental is sues and is sues relating to other aspects of the sustainable development pillars (society and economy) can beintegrated in the procurement with a view to enhance their supply chain performance" (p. 63). The findings also showed that the influence of these procurement procedures was perceived to differ on the environmental management of the clas sified hotels.

A Chi-Square test was run to determine the relationship between the procurement procedures 20 

hotels in Mombasa County, Kenya - Hotel and Tourism Management, 2020, Vol. 8, No. 1: 11-23.

and environmental management in clas sified hotels in Mombasa County, Kenya. The results are shown in Table 10.

Table 10: Chi-test for procurement procedures and environmental management

\begin{tabular}{|l|c|c|c|c|c|}
\hline $\begin{array}{l}\text { Independent } \\
\text { variable }\end{array}$ & Hypothesis & $\begin{array}{c}\text { Chi-sq. p } \\
\text { value }\end{array}$ & $\begin{array}{c}\text { Sig. } \\
\text { Value }\end{array}$ & Result & Decision \\
\hline $\begin{array}{l}\text { Procurement } \\
\text { Procedures }\end{array}$ & $\mathrm{H}_{01}$ & 0.028 & 0.05 & $0.028<0.05$ & $\begin{array}{c}\mathrm{H}_{01}: \\
\text { rejected }\end{array}$ \\
\hline
\end{tabular}

Source: Author's research, 2017

Table 10 shows at $95 \%$ confidence level, the Null Hypothes is $\left(\mathrm{H}_{01}:\right)$ yielded Pearson's Pvalue $<0.05$, hence, the Null hypothesis $\left(\mathrm{H}_{01}\right.$ : There is no significant relationship between the procurement procedures and environmental management in clas sified hotels in Mombasa County, Kenya) was not accepted. Consequently, the alternative hypothes is (There is a significant relationship between the procurement procedures and environmental management in classified hotels in Mombasa County), Kenya was accepted.

\section{Conclusion}

The findings indicate that procurement procedures influence environmental management. However, some of the procurement procedures were perceived to have greater influence than others. The most influential procurement procedure on environmental management was tendering adverts that attract suppliers offering environmentally friendly products while the least influential one was assessing the impact of suppliers on the environment prior to purchasing. The overall survey findings revealed that the respondents perceived the following parameters to have an influence on environmental management in the classified hotels: tendering adverts that attract suppliers offering environmentally friendly products, having bidders that meet environmental certification standards, assessing of suppliers on environmentally friendly practices, having suppliers comply with the acceptable environmental certification standards, all bidders meet environmental certification standards, assessing the impact of suppliers on the en vironment prior to purchasing and only purchasing from suppliers selling environmentally friendly products.

The purpose of this paper was to examine the role of procurement procedures in environmental management. The study concluded that procurement procedures influenced environmental management. The study recommends that hotels should embrace all the procurement procedures that contribute to environmental management so as to enjoy their benefits, in particular, tendering adverts that attract suppliers offering environmentally friendly products. The hotels should als obe encouraged to carry out an impact assessment of the suppliers on the environment prior to purchasing.

\section{Acknowle dgments}

Special appreciation to Mr. Silvanus Mukai for the special aid he accorded us in coming up with this paper and to our colleagues for the pieces of advice they gave no matter how small.

\section{References}

1. Amemba, M. (2013). Logistics \& supply chain management (41st ed.). London, United Kingdom: Pearson Education.

2. Butler, J. (2015). The compelling "hard case" for "green" hotel development. Cornell 
Odeny, J. A. et al. - The role of procurement procedures in environmental management: A case study of classified hotels in Mombasa County, Kenya - Hotel and Tourism Management, 2020, Vol. 8, No. 1: 11-23.

Hospitality Quarterly, 49(3), 234-244. https ://doi.org/10.1177/1938965508322174

3. Carter, C. (2014). Social res ponsibility and supply chain relationships. Transportation Research Part E: Logistics and Transportation Review, 38(1), 37-52. https://doi.org/10.1016/S1366-5545(01)00008-4

4. Chan, W., Wong, K., \& Lo, J. (2015). Hong Kong hotels' sewage: Environmental cost and saving technique. Journal of Hospitality \& Tourism Research, 33(2), 329-346. https://doi.org/10.1177/1096348009338525

5. Chege, E. (2012). Green supply chain management and supply chain performance of private hospitals in Nairobi Kenya (Unpublis hed MBA project). University of Nairobi, Kenya.

6. Chiu, J.-Z., \& Hsieh, C. C. (2015). The impact of restaurants' green supply chain practices on firm performance. Sustainability, 8(1), 1-14. https://doi.org/10.3390/su8010042

7. Cooper, D., \& Schindler, P. (2003). Business research methods (8th ed.). New York, USA: McGraw-Hill.

8. Denscombe, M. (2008). Communities of practice: A research paradigm for the mixed methods approach. Journal of Mixed Methods Research, 2(3) 270-283. https://doi.org/10.1177/1558689808316807

9. Green, K. W.,Zelbst, P. J., Meacham, J., \& Bhadauria, V. S. (2012). Green supply chain management practices: Impact on performance. Supply Chain Management, 17(3), 290 305. https://doi.org/10.1108/13598541211227126

10. Hoske, S. (2015). Benchmarking supply chain sustainability: Insights froma field study. Benchmarking: An International Journal, 18(5), 705-732. https://doi.org/10.1108/14635771111166839

11. Janković, S., \& Krivačić, K. (2014). Environmental accounting as pers pective for hotel sus tain ability: Literature review. Tourism and Hospitality Management, 20(1),103-120.

12. Kenya TourismFederation (2014, February). Daily Nation Newspaper: Statement by the Kenya tourism industry. Nation Media Group Ltd, Kenya.

13. Khisa, J. (2011). Green procurement in public sector a case of parastatals in Kenya (Unpublished MBA project). University of Nairobi, Kenya.

14. KNBS (Kenya National Bureau of Statistics) (2016). Economic survey. Nairobi, Kenya: Government Press.

15. Knudsen,D. (2013). Improving procurement performance withe-business mechanisms. $\mathrm{PhD}$ thes is, Lund University, Sweden.

16. Kothari, C. (2004). Research methodology: Methods and techniques (2nd Revised). New Delhi, New Age International (P) Ltd.

17. Manyara, G., \& Jones, E. (2007). Best practice model for community capacity-building: A case study of community-based tourism enterprises in Kenya. Tourism, 55(4), 403415.

18. Mensah, I. (2016). Environmental management practices among hotels in the greater Accra region. International Journal of Hospitality Management, 25(3), 414-431. https://doi.org/10.1016/j.ijhm.2005.02.003

19. Mugenda, O., \& Mugenda, G. (2003). Research methods: Quantitative and qualitative approaches. African Centre for Technology Studies.

20. Murutu, T. (2016). Green supply chain implementation: Best practices and challenges. AIBUMA conference, School of Busines s, University of Nairobi.

21. Perry, J., \& Sohal, H. (2009). Creating a green supplychain information technology as an enabler for a green supply chain. Retrieved April 30, 2020 from https://www.semanticscholar.org/

22. Sarkis, J. (2001). Manufacturing's role in corporate environmental sustainability: Concerns for the new millennium. International Journal of Operations and Production Management, 21(5/6), 666-686. https://doi.org/10.1108/01443570110390390 

hotels in Mombasa County, Kenya - Hotel and Tourism Management, 2020, Vol. 8, No. 1: 11-23.

23. Siem, T. (2005). Supply chain management: The science of better, faster, cheaper. Southwest Economy, 2, 7-12.

24. Srivastava, S. K. (2005). Profit driven reverse logistics. International Journal of Business Research, 4(1), 53-61.

25. Sustainable Tourism Report (2013). Our common future: Report of the World Commission on Environment and Development.

26. Trochim, J. (2001). The relationship between top managers' environmental attitudes and environmentalmanagement in hotel companies. Virginia Polytechnic Institute and State University, Virginia.

27. Wu, M., Ye Bi, H., Cai, J., \& Huang, Z. (2012). The relation between consumer behavior toward environmental protection and their hotel preference. Study of Environment and Management, 4(2), 61-81.

28. Yamane, T. (1967). Statistics: An introductory analysis (2nd ed.). New York: Harper and Row. 